7. Reprod. Fert. (1973) 34, 159-163

\title{
THE EFFECT OF CALORIC RESTRICTION ON TESTICULAR HYPERTROPHY FOLLOWING HEMICASTRATION IN THE RAT
}

\author{
SHEILA F. STEWART, D. GAWLAK AND SUSAN KOPIA \\ Warner-Lambert Research Institute, \\ Morris Plains, New Fersey 07050, U.S.A.
}

(Received 28th December 1972)

Hemicastration in the rat is followed by hypertrophy of the remaining gonad (Heller, Heller \& Sevringhaus, 1942), presumably as a result of increased pituitary secretion of gonadotrophins (Benson, Sorrentino \& Evens, 1969). Howland (1972) recently demonstrated that caloric restriction interfered with ovarian hypertrophy and speculated that this was due to a decreased level of hypothalamic releasing factors. The present study was undertaken to determine if caloric restriction affected gonadal hypertrophy in the male as in the female.

Immature Sprague-Dawley male rats, weighing 35 to $40 \mathrm{~g}$, were used since the mature male does not respond with gonadal hypertrophy when hemicastrated (Means \& Hall, 1967). For comparison with the results obtained by Howland (1972), adult female rats weighing 160 to $180 \mathrm{~g}$ were used, but for comparison with the males, an immature female was used. Both sexes were hemicastrated by removing the right gonad. Within $24 \mathrm{hr}$ of the operation, a food restriction of $50 \%$ was imposed and continued for 14 days; the animals were housed individually, the food intake of the intact and hemicastrated controls was measured daily and the experimental animals were fed $50 \%$ of these amounts. On the 15 th day after the operation, the animals were killed and the left gonads from both the intact and hemicastrate rats were removed and weighed. Although different methods of observation from those of Howland (1972) were used, a $50 \%$ caloric restriction in the adult female prevented the ovarian compensatory hypertrophy; in the immature female, the hypertrophy was curtailed considerably. In the immature male rat, however, the gonadal hypertrophy was not affected (Table 1).

Since the hemicastrated male showed gonadal hypertrophy when fed a restricted diet for 2 weeks, a preoperative period of dieting was also studied. Immature male rats were allocated to two groups. Those in one group were restricted in caloric intake 10 days before hemicastration and, in the other group, at the time of operation. In both groups, the restriction was continued for another 14 days. The experimental animals were compared to intact rats having similar dietary regimens (Table 2).

At the time of the operation, the rats were 10 days older than those in the first experiment, which would account for the fact that the fully fed rats showed little or no gonadal hypertrophy. In those on a restricted intake for 14 and 24 


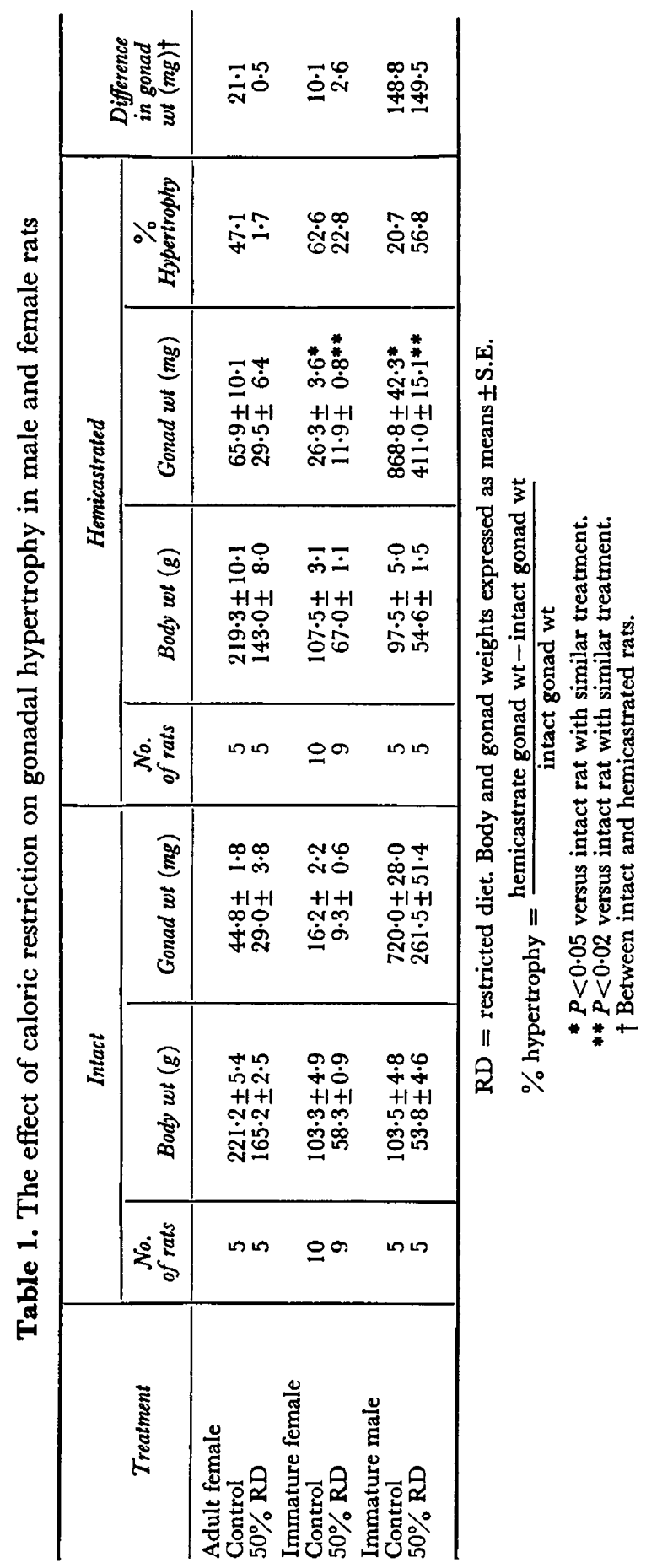



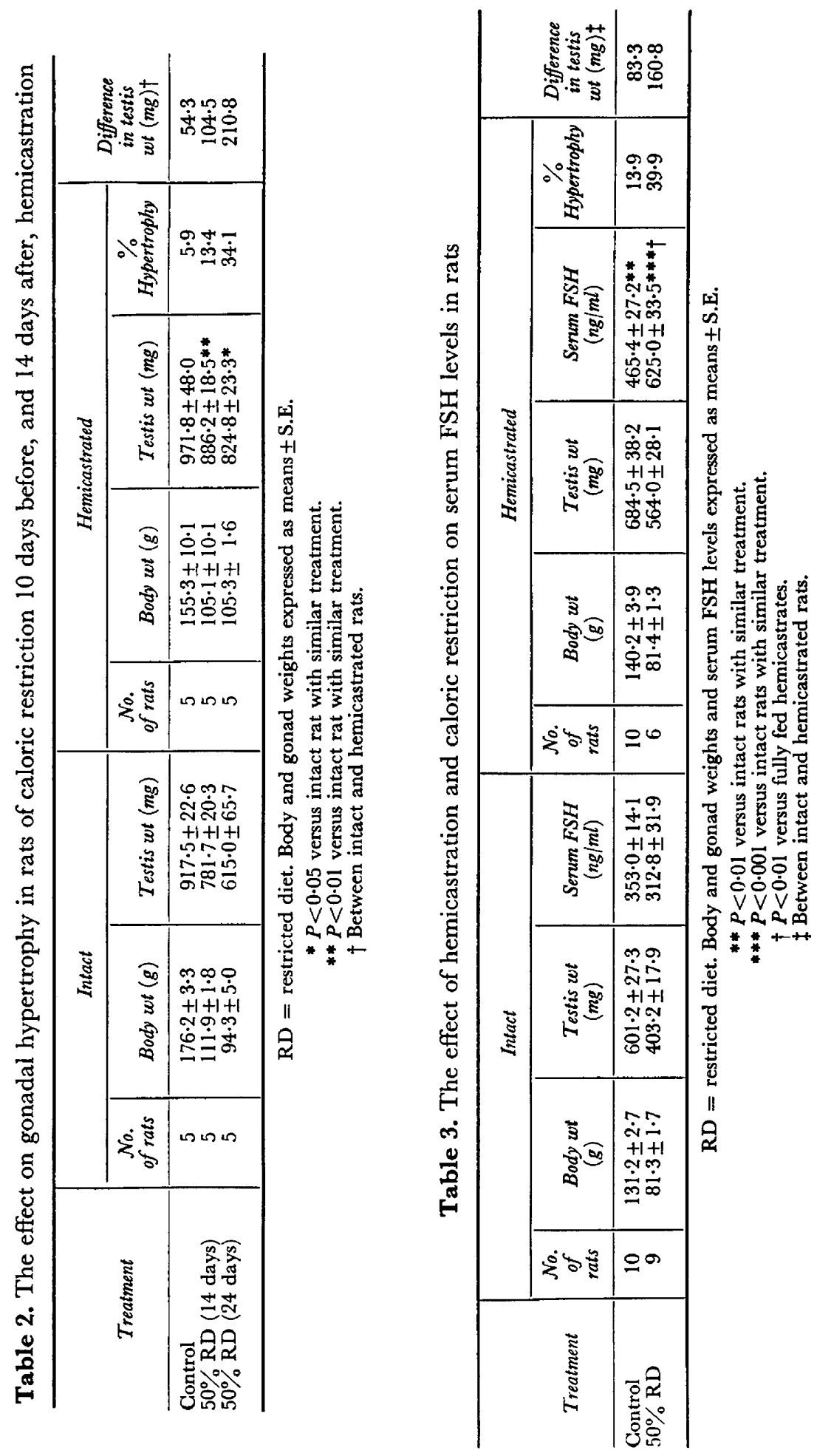
days, the growth of the testis in the hemicastrates exceeded the similarly fed intact controls by 13 and $34 \%$, respectively. The weight change in both instances was statistically significant. Thus, caloric restriction in the hemicastrated immature rat stimulated postoperative gonadal growth beyond that obtained in fully fed animals.

In a third experiment, similar to the first, the serum FSH levels were determined by radioimmunossay (Greenwood, Hunter \& Glover, 1963; Berson, Yallow, Glick \& Roth, 1964). The hemicastrated rats of both groups had serum FSH levels which were significantly greater than their intact controls, and the increase was significantly greater when the diet was limited (Table 3 ).

Root \& Russ (1972) also found an increased serum FSH level in adult and immature starved male rats following castration, and suggested that the higher concentration of FSH might be associated with lowered plasma volume as a result of underfeeding. Both in their experiment and ours, however, the lowered volume of the intact underfed rat did not increase the FSH levels, nor did a decreased amount of testicular tissue, also found in the underfed rat, have any effect. The evidence implied that the greater FSH concentrations were the result of increased secretions of the hormone following castration (Root \& Russ, 1972) or hemicastration and further augmented by a decreased feed intake.

It was notable that the increased gonadal growth was associated with the higher levels of FSH, a hormone which has been reported to stimulate the weight of immature rat testes (Lostroh, 1969).

The response of the immature male rat was different from that of the adult and immature female rat when subjected to a $50 \%$ restricted caloric intake. Instead of the imposed diet interfering with gonadal hypertrophy, as in the female, the immature male responded with an increased percentage testis growth over and above that of the fully fed hemicastrate. In fact, the longer the diet was imposed on the hemicastrate, the greater was the percentage of growth. In both hemicastrate groups, the degree of hypertrophy was accompanied by a commensurate increase in plasma FSH concentration which may be responsible for the testicular hypertrophy. The reason for this response to restricted feed intake in the hemicastrated male rat was not clear.

The authors are grateful for the purified rat FSH (NIAMD-Rat-FSH-I-1) and rabbit-anti-Rat-FSH-serum-3 and NIAMD-Rat-FSH-RP-1 provided by the National Institute of Arthritis and Metabolic Diseases, Rat Pituitary Hormone Program.

\section{REFERENGES}

Benson, B., Sorrentino, S. \& Evans, J. S. (1969) Increase in serum FSH following unilateral ovariectomy in the rat. Endocrinology, 84, 369.

Berson, S. A., Yallow, R. S., Glick, S. M. \& Roth, J. (1964) Immunoassay of protein and peptide hormones. Metabolism, 13, 1135.

Greenwood, F. G., Hunter, W. M. \& Glover, J. S. (1963) The preparation of I $^{131}$-labelled human growth hormone of high specific radioactivity. Biochem. 7. 89, 114.

Heller, G. G., Heller, E. J. \& Sevringhaus, E. L. (1942) Does estrogen substitution materially inhibit pituitary gonadotropic potency? Endocrinology, 30, 309. 
HowLAND, B. E. (1972) Ovarian weight and ovarian compensatory hypertrophy in the rat as affected by duration of underfeeding. F. Reprod. Fert. 28, 321.

LostroH, A. J. (1969) Regulation by FSH and ICSH (LH) of reproductive function in the immature male rat. Endocrinology, 85, 438.

Means, A. R. \& Hall, P. F. (1967) Effect of FSH on the protein biosynthesis in the testis of the immature rat. Endocrinology, 81, 1151.

Root, A. W. \& Russ, R. D. (1972) Short term effects of castration and starvation upon pituitary and serum levels of luteinizing hormone and follicle stimulating hormone in male rats. Acta endocr., Copenh. 70, 665 . 